\title{
COMMENTS
}

\section{TRADING CLAIMS IN CHAPTER 11: HOW MUCH INFLUENCE CAN BE PURCHASED IN GOOD FAITH UNDER SECTION 1126?}

\author{
Andrew Africk $†$
}

\section{INTRODUCTION}

Paradoxically, being involved with a company in bankruptcy can be extremely profitable. As in so many other areas of life, the key is timing. Profits are made by buying debt claims against bankrupt companies at distressed prices and negotiating advantageous treatment of those claims in the plan of reorganization. ${ }^{1}$ While trading claims on distressed debtors is not a new business, ${ }^{2}$ it has reached new heights of popularity in recent years. Pension funds and other institutional investors have contributed more than $\$ 3$ billion to "vulture" or "debt raider" funds, which buy strategic blocks of debt issued by companies facing bankruptcy. ${ }^{3}$ The increased investor interest in participating in chapter 11 situations has been paralleled by an increasing supply of distressed debtors. ${ }^{4}$ The result has been the development of an active market in claims on insolvent companies. ${ }^{5}$

† B.A. 1988, UCLA; M.B.A. Candidate 1992, Wharton Business School, University of Pennsylvania; J.D. Candidate 1992, University of Pennsylvania.

1 See 'Debt Raiders' See Bull Market in Bankruptcies, L.A. Times, Oct. 21, 1990, at D1, col. 6 [hereinafter 'Debt Raiders'].

${ }^{2}$ See Fortgang \& Mayer, Trading Claims and Taking Control of Corporations in Chapter 11, 12 CARDOZO L. REV. 1, 25-26 (1990) (noting that 29 of the 64 members of the First United States Congress bought steeply discounted debt securities issued by the states to fund the Revolutionary War while the Congress considered legislation calling for the federal government to assume the states' debts and pay them in full).

${ }^{3}$ See Schifrin, Pay Up . . . or Else, Forbes, Aug. 6, 1990, at 74, 74-75. Chilmark Partners, a Chicago investment firm, has raised $\$ 1$ billion for its vulture fund while Goldman, Sachs \& Co. has launched a fund with $\$ 783$ million in capital. The Goldman fund projects annual returns of 25-35\%. See 'Debt Raiders, 'supra note 1.

I See Total of Defaults for Junk Bonds Soared Last Year, Wall St. J., Jan. 9, 1991, at $\mathrm{C17}$, col. 6 ("Defaults of corporate junk bonds soared to a record $\$ 24.6$ billion in 1990 , equal to $8.5 \%$ of the high-yield issues outstanding and more than double 1989's default total. ... [M] unicipal-bond defaults climbed to $\$ 1.4$ billion in 1990 , a $37 \%$ increase from 1989's $\$ 1.02$ billion.").

${ }^{5}$ See Schifrin, supra note 3 , at 74 . 
An investor who buys debt claims on a company in bankruptcy hopes to profit in one of three ways: (1) by participating in a reorganization plan which gives the investor cash and securities valued at more than that invested, ${ }^{6}$ (2) by exchanging the purchased claims for particular assets owned by the debtor, ${ }^{7}$ or (3) by effecting a reorganization plan in which the investor exchanges purchased debt claims for all or part of the equity of the debtor. ${ }^{8}$ Each of these avenues requires that the investor exert a degree of influence over the reorganization planning process in order to ensure favorable treatment of his claims. ${ }^{9}$

Influence in the reorganization process can be gained by shrewd diplomacy or through a strategic legal position. A powerful legal position in a chapter 11 case can be obtained by purchasing $34 \%$ of the face amount of a well chosen class of debt securities. The Bankruptcy Code requires that two-thirds in amount and one-half in number of allowed claims voting in each class opt to accept the reorganization plan in order for that plan to be confirmed. ${ }^{10}$

${ }^{6}$ See, e.g., In re Odd Lot Trading, Inc., 115 Bankr. 97, 99 (Bankr. N.D. Ohio 1990) (relating that investor arranged to buy claims at 60 cents on the dollar where proposed reorganization plan provided for payment of 80 cents on the dollar in cash plus a share of earnings on invested funds probably worth an additional five cents on the dollar).

7 See, e.g., In re Apex Oil Co., 92 Bankr. 847, 849-50 (Bankr. E.D. Mo. 1988) (reporting that investor bargained to receive debtor's refinery assets valued at more than $\$ 545$ million in exchange for $\$ 545$ million face amount of secured notes that investor had purchased from lenders for $\$ 396$ million).

${ }^{8}$ See, e.g., In re Allegheny Int'l, Inc., 118 Bankr. 282, 286 (Bankr. W.D. Pa. 1990) (relating that investor Japonica Partners sought a plan of reorganization which would give it a controlling equity stake in the debtor in exchange for purchased claims).

${ }^{9}$ Several sections of the Bankruptcy Code address the form and function of the plan in the bankruptcy reorganization process. See 11 U.S.C. $\$ \S 1121-29$ (1988). There is a requirement that the plan specify the treatment of each class of claimant. See id. \$1123(a)(3)-(4).

${ }^{10}$ Section $1126(c)$ states:

A class of claims has accepted a plan if such plan has been accepted by creditors, other than any entity designated under subsection (e) of this section, that hold at least two-thirds in amount and more than one-half in number of the allowed claims of such class held by creditors, other than any entity designated under subsection (e) of this section, that have accepted or rejected the plan.

Id. $\$ 1126(\mathrm{c})$.

Another section provides, in relevant part: “(a) The court shall confirm a plan only if all of the following requirements are met .... (8) With respect to each class of claims or interests-(A) such class has accepted the plan; or (B) such class is not impaired under the plan." Id. § 1129.

Of course, the requirement that every class accept the plan can be circumvented by (1) leaving the rejecting class unimpaired in accordance with 11 U.S.C. $\$ 1124$ 
Thus, a debt purchaser who holds $34 \%$ of an impaired class holds a blocking position whereby he can prevent the debtor from confirming any plan which does not treat advantageously the purchased claims. Without confirmation of a reorganization plan, the debtor cannot emerge from bankruptcy.

The influence which a debt raider can exert by virtue of his blocking position is not absolute, however. Economically, the longer the debt raider delays confirmation, the longer he goes without any return on his investment. The opportunity costs can become substantial. Legally, 11 U.S.C. $\$ 1126(e)$ gives a bankruptcy court the power to designate (disqualify) the vote of any claimant who voted in "bad faith." 11 However, what constitutes bad faith in voting is not clear. Neither "good faith" nor "bad faith" is defined in the Bankruptcy Code. Therefore, judges face the challenge of reconciling the majority's right to overcome a "nuisance" with the minority's right to appraise the proposed plan and cast its vote in its own self interest. Court decisions are understandably split as to how permissive the good faith standard is. ${ }^{12}$ Meanwhile, voting power affects the influence which the parties have relative to each other in the reorganization plan negotiations because the negotiations are always a prelude to a vote. Thus, the parties involved in a chapter 11 bankruptcy are vitally interested in knowing when the line into bad faith is crossed.

Part I of this Comment outlines the mechanics of trading claims against distressed debtors and the role of the claim purchaser. Part II examines the existing Bankruptcy Code provision concerning good faith in voting and the history behind it. Part III argues that the recent court decisions applying section 1126(e) have given insufficient guidance to practitioners and do not adequately take into account changing market conditions. Part IV establishes a

(1988), or (2) resorting to a "cram-down" proceeding under 11 U.S.C. $\$ 1129(\mathrm{~b})$ (1988). See Klee, All You Ever Wanted to Know About Cram Down Under the New Bankruptcy Code, 53 AM. BANKR. L.J. 133 (1979). These possibilities, however, are not to be feared by the shrewd debt raider. Because the distressed debt is usually purchased at a deep discount, the purchaser will reap large profits from a plan which leaves his class unimpaired. Further, as long as the purchaser buys claims which belong to a sufficiently large or sufficiently senior class, the debtor is unlikely to have the resources to effect a cram-down. See id. at 154.

11 This section states: "On request of a party in interest, and after notice and a hearing, the court may designate any entity whose acceptance or rejection of such plan was not in good faith, or was not solicited or procured in good faith or in accordance with the provisions of this title." 11 U.S.C. \$ 1126(e) (1988).

${ }^{12}$ See infra notes 78-119 and accompanying text. 
framework for applying the section 1126(e) good faith in voting requirement to claim purchasers in the future. This Comment concludes that a presumption of good faith in favor of the claim purchaser is necessary.

\section{Trading Glaims}

\section{A. Mechanics}

Investors buy claims against bankrupt companies by taking assignment of those claims. The purchaser steps into the shoes of the seller, assuming all of the rights and infirmities of the purchased claim. ${ }^{13}$ In most cases, the assignment carries the right to enforce the claim at par. ${ }^{14}$

13 See Goldie v. Cox, 130 F.2d 695, 720 (8th Cir. 1942) (stating that an assignee is subject to all equitable claims against the assignor); Fortgang $8:$ Mayer, supra note 2, at 13 n.74 (citing, inter alia, Shropshire, Woodliff \& Co. v. Bush, 204 U.S. 186 (1907) (holding that priority wage claims remain priority claims in hands of claims purchasers)).

${ }^{14}$ See Moulded Prods., Inc. v. Barry, 474 F.2d 220, 224-25 (8th Cir.), cert. denied, 412 U.S. 940 (1973); Kremer v. Clarke (In re Frank Fehr Brewing Co.), 268 F.2d 170, 180 (6th Cir. 1959), cert. denied, 362 U.S. 963, reh'g denied, 363 U.S. 817 (1960) ("As a general proposition, it is not against public policy for a creditor to assign a claim to a purchaser even though it be for less than face value."); In re Lorraine Castle Apartments Bldg. Corp., 149 F.2d 55, $57-58$ (7th Cir.), cert. denied, 326 U.S. 728 (1945) ( ${ }^{\text {[ }}[\mathrm{T}]$ he prices which security holders pay for their securities in no wise affects the measure of their participation in reorganization or their voting power."); Standard Gas \& Elec. Co. v. Deep Rock Oil Corp., 117 F.2d 615, 619 (10th Cir.), cert. denied, 313 U.S. 564 (1941); Security-First Nat'l Bank v. Rindge Land \& Navigation Co., 85 F.2d 557, 561 (9th Cir.), reh'g denied, 86 F.2d 3 (9th Cir.), cert. denied, 299 U.S. 613 (1936), reh'g denied, 300 U.S. 686 (1937) ("The legal value or property right in an obligation is the right to recover from the maker to the entire extent of his promise to pay. The consideration given for a security by the holder thereof is immaterial."); In re Automatic Equip. Mfg. Co., 106 F. Supp. 699, 706-07 (D. Neb. 1952), appeal dismissed, 202 F.2d 955 (8th Cir. 1953).

The exception to the right to enforce an assigned claim at par comes into play when the assignee is found to have a fiduciary obligation to the bankrupt estate. See Fortgang \& Mayer, supra note 2, at 25-38. A fiduciary obligation could possibly arise from service on an official committee, see id. at 36 , or from obtaining substantial nonpublic information from the debtor. See In re Allegheny Int'l, Inc., 118 Bankr. 282, 297-99 (Bankr. W.D. Pa. 1990) (holding that Japonica Partners became a fiduciary because the debtor gave it substantial nonpublic information in connection with Japonica's attempt to offer a plan in which Japonica would acquire the debtor). But see SEC Backs Trading By The Bondholders On Bankruptcy Panels, Wall St. J., Feb. 6,1991 , at A7, col. 3 (quoting an amicus brief filed by the SEC in the Allied Stores bankruptcy arguing that bondholders who sit on official committees should still be allowed to trade even though they are "temporary insiders" because to hold otherwise would deprive debtors' committees of needed expertise). 
Bankruptcy Rule 3001(e) provides the mechanism through which transfers of claims are formally effected. ${ }^{15}$ On its face, Rule 3001 (e) only requires that the transfer of the claim be unconditional and that the court be properly noticed of the transfer. ${ }^{16}$ It has been suggested that Rule 3001(e) should serve more than an administrative function by requiring adequate disclosure to transferors of what they may be entitled to if they hold their claims until plan confirmation. ${ }^{17}$ At least three bankruptcy court judges have agreed, finding some implicit requirement of disclosure within Rule 3001(e). ${ }^{18}$ The Judicial Conference Advisory Committee on Bankruptcy Rules has proposed a new draft of Rule 3001(e)(2), but it does not enlarge the essentially administrative role envisioned for the court by the existing rule. ${ }^{19}$

\section{B. Trading: Reorganization Help or Hindrance?}

A court's treatment of the interests of a claims purchaser will depend to a large extent on whether the judge views the purchaser as a help or hindrance to the reorganization process. Intuitively, a judge is more likely to find that the claims purchaser acted and voted in bad faith if that judge has a negative view of the role played by the purchaser in the case. Accordingly, articulating the costs and benefits of claim purchaser involvement proves useful.

15 See FED. R. BANKR. P. 3001(e).

${ }^{16}$ See id. Rule 3001(e)(1) addresses claim transfers before proofs of claims have been filed whereas Rule 3001(e)(2) deals with the post-proof case.

${ }^{17}$ See Note, Post-Petition Trading in Chapter 11 Claims: A Call for Augmentation of Federal Rule of Bankruptcy Procedure 3001(e)(2), 58 FORDHAM L. REV. 1053, 1061 (1990) ("Without regulation that specifically addresses inadequate disclosure, the chapter 11 claims market will continue to operate without the information necessary to ensure a fair and free marketplace.").

${ }^{18}$ See In re Allegheny Int'l, Inc., 100 Bankr. 241, 242 (Bankr. W.D. Pa. 1988) (ordering transferees to give time to transferors to rescind their assignments where claims were purchased at large discounts and plan of reorganization called for $100 \%$ payoff, even though transferors were sophisticated financial institutions and had not raised objections); In re Revere Copper \& Brass, Inc., 58 Bankr. 1, 3 (Bankr. S.D.N.Y. 1985) (requiring transferees to give increased disclosure and to allow transferors to rescind sale even though no transferor had raised an objection); Supplement to the Requirements of Fed. R. Bankr. P. 3001(e)(2) (Lifland, C.J.) (No. 86 B 11276) (establishing chamber rules requiring increased disclosure by trade claim transferees to both the court and potential transferors).

19 See Committee on Rules of Practice and Procedure of the Judicial Conference of THE UNITEd STATES, Prel.Mminary DRAFT OF Proposed AMENDMENTS TO THE BANRRUPTCY RULES (Aug. 1989), reprinted in 265 Bankr. L. Rep. (CCH) 77-78 (Oct. 12, 1989). 
Judge Lifland of the Southern District of New York has expressed some of the perceived negative effects of trafficking in claims:

Clearly, one of the 'evils' spawned by bankruptcy claims trading in 'mega' cases, the size of Eastern [Air Lines], 'is the substantially increased burden associated with monitoring, administering and objecting to claims which have been filed against the estate. This increased administrative burden diverts the limited resources of the Debtor's estate and has the potential for impeding the reorganization process. Moreover, the Assignment, and other transactions similar in kind, has the effect of uncontrollably multiplying claims which, in turn, significantly increases the administrative burden imposed on the estate associated with claims administration. ${ }^{20}$

In addition to the administrative burdens discussed above, Judge Lifland and others believe that the transferor is often taken advantage of by a transferee who has superior knowledge of the financial and operational state of the debtor and superior knowledge of the chapter 11 process. $^{21}$

Other critics believe that opportunities for any particular player in the reorganization process to cause delay should be minimized. ${ }^{22}$ The argument follows that to the extent a claims purchaser brings delay by bargaining harder or vetoing a reorganization plan, he causes an inferior result.

${ }^{20}$ In re Ionosphere Clubs, Inc., 119 Bankr. 440, 444 (Bankr. S.D.N.Y. 1990). This case involved a transferee (Amroc) who bought $\$ 2,547,312$ face amount of trade claims from Marriot for $\$ 2,114,269$. See id. at 441 . Amroc wanted the court to void the transfer on the grounds that Marriot had not sold the entirety of its claim to Amroc, violating the court's policy against splitting claims. See id. at 443. Amroc did not want to complete the deal because Eastern's financial status had deteriorated and the claims were not worth what Amroc had paid Marriot. See id. at 442. Ironically, Judge Lifland approved the transfer, saddling Amroc with substantial losses. See id. at $446-47$.

${ }^{21}$ Demanding increased disclosure by transferees and giving transferors an opportunity to rescind assignment agreements implies that transferors are at an informational disadvantage. See supra notes 17-18. See also 'Debt Raiders, 'supra note 1 , at D8, col. 3 ("There's a potential for conflict with the bankruptcy court judge, who may view a debt buyer as a disruptive force or unfair to other claim holders.").

22 One such critic points out:

Each of the critical actors in reorganization can, by making a decision (to delay, to litigate, to reject a plan of reorganization), cause the firm and those with a claim on, or interest in, the firm to bear costs of delay. The 
Judge Lifland notes that bankruptcy courts do not lack a remedy for these perceived ills:

Bankruptcy courts are afforded the power to limit or prevent bankruptcy claims trading where taking such action ... will relieve the debtor and its estate from a great administrative burden. In addition to this Court's inherent authority under Bankruptcy Rule 3001(e)(2), § 105 of the [Bankruptcy] Code also authorizes this Court to fashion appropriate remedies to protect against threatened harm to, or interference with the sound administration of the estate. ${ }^{23}$

Courts have rarely expounded on the benefits of trading claims, preferring to note simply that "it is not against public policy. ${ }^{24}$ In fact, the participation of a purchaser of claims could substantially benefit parties to the reorganization. Liquidity is the most apparent benefit. The claims purchaser offers creditors the opportunity to extricate themselves from the bankruptcy now at a sum certain rather than waiting for an uncertain payoff at an uncertain time. ${ }^{25}$ The liquidity may be particularly useful to claimants such as trade creditors or employees who prefer to recoup losses through future business relationships with the debtor. If these creditors were to retain and press their claims, they would be forced to take an

decisionmaker bears only some of the costs that the decision triggers. This is, in the jargon of game theory, a basic form of the prisoner's dilemma: the aggregation of individualistic, 'rational' decisions leads to an inferior collective result.

Roe, Bankruptcy and Debt: A New Model for Corporate Reorganization, 83 CoLUM. L. REV. 527, 544 (1983) (footnote omitted).

${ }^{23}$ In re Ionosphere Clubs, 119 Bankr. at 445. Section 105(a) gives the bankruptcy court the power to "issue any order, process, or judgment that is necessary or appropriate to carry out the provisions of this title." See 11 U.S.C. $\$ 105$ (a) (1988).

24 Kremer v. Clarke (In re Frank Fehr Brewing Co.), 268 F.2d 170, 180 (6th Cir. 1959), cert. denied, 362 U.S. 963, reh'g denied, 363 U.S. 817 (1960). The rare case is In re Lorraine Castle Apartments Bldg. Corp., 149 F.2d 55, 57-58 (7th Cir. 1945), cert. denied, 326 U.S. 728 (1945) (defending the claim speculator's role in the reorganization process).

${ }^{25}$ See Fortgang \& Mayer, supra note 2, at 4-5 (noting that many types of debt including privately placed debt securities, bank loan claims, personal injury claims, and claims for the rejection of executory contracts do not trade on any exchange and prove illiquid and that the value of these debts is reduced by the brokerage costs, due diligence costs, and time costs involved in selling them as well as by the credit risk). See also 'Debt Raiders,' supra note 1, at D8, col. 2 (explaining that "their investments do have the salutary effect of allowing bankers, junk bond holders and trade creditors to extricate themselves from bitter and time-consuming bankruptcies"). 
adversarial role against the debtor to obtain full value, possibly damaging future relations. ${ }^{26}$

Contrary to Judge Lifland's concerns, ${ }^{27}$ the claims purchaser may reduce the administrative burden on the debtor by consolidating many claims into one set of professional hands. The investor, who has a large financial stake in the chapter 11 debtor, "has a greater interest in the case which justifies the investor's commitment of time and money." ${ }^{28}$ Communication with creditors is made easier because there are fewer of them. Further, the investor alleviates the collective action problem which makes active participation by and coordination among creditors difficult. ${ }^{29}$

The purchase of the debt claims may also serve to relieve the debtor of contentious relations with the original lender group. ${ }^{30}$ Of course, a claims purchaser intent on receiving full value could have more contentious relations with management than the transferors had if the latter were complacent in pressing their claims. .1 $^{\text {1 }}$

In addition to bringing the benefits of liquidity and consolidation, the claims purchaser may enhance the debtor's chances for successfully reorganizing by being eager to accept securities ${ }^{32}$ while other creditors are not. ${ }^{33}$ In fact, the most predominant set of

26 See Fortgang \& Mayer, supra note 2, at 5.

27 See supra notes $20-21$ and accompanying text.

${ }^{28}$ Fortgang \& Mayer, supra note 2, at 6. Ronald LaBow, whose Stonehill Investment converted $\mathbf{\$ 3 0 0}$ million face amount of debt in Wheeling-Pittsburgh Steel for a controlling equity stake, said the time commitment of these investments is so enormous and the complexity so great that "[i]f you can do two of these at once you are very fortunate." 'Debt Raiders, 'supra note 1, at D8, col. 5.

29 See generally M. OLSON, THE LOGIC OF COLLECTIVE ACTION 2 (1971) (noting that rational, self-interested individuals generally will not act to achieve group interests); Brudney, Equal Treatment of Shareholders in Corporate Distributions and Reorganizations, 71 CALIF. L. REV. 1073, 1074 (1983) (describing conflicting pressures to maximize enterprise value and to accord equal treatment to investors).

${ }^{30}$ See, e.g., In re Apex Oil Co., 92 Bankr. 847, 864 (Bankr. E.D. Mo. 1988) (recounting the contentious relations between debtor and its original lender group in which lender group threatened to force liquidation and debtor threatened lender liability litigation which would take years to adjudicate).

31 See All eyes on Distressed Companies: Takeovers of Distressed Companies on the Rise, CORP. FINANCING WEER, Sept. 17, 1990, at 1, 10 ("Managements will increasingly be forced to handle not only their financial trouble, but negotiations with sophisticated creditors, rather than unsophisticated inadvertent creditors, caught off guard by a company's restructuring or bankruptcy.").

${ }^{32}$ See Fortgang \& Mayer, supra note 2, at 7 (noting in one case that "assignees of bank creditors [were] to receive 50\% of reorganized debtor's stock," and in a second case that a claims purchaser "received $35 \%$ of the debtor's equity in return for debentures purchased ${ }^{n}$ ).

33 Professor Roe points out: 
creditors, banks, are legally prevented from taking long term equity stakes in exchange for debt. ${ }^{34}$ A claims purchaser making an exchange for an equity stake strengthens the debtor's balance sheet by decreasing the debt-to-equity ratio. This strength can, in turn, facilitate new borrowing. ${ }^{35}$ By supplying liquidity to creditors and capital to debtors, a claims purchaser can be of substantial benefit to the reorganization process.

\section{BANKRUPTCY CODE SECTION 1126(e) AND ITS HISTORY}

The legislative history of section $1126(e)^{36}$ does not suggest that Congress gave much thought to the costs or benefits of claim purchaser participation. The legislative history also provides little guidance on what elements of a claim purchaser's behavior constitute bad faith such that his votes should be disqualified. ${ }^{37}$ The statement in the House Report accompanying section 1126(e) was extremely limited in its examples of bad faith. ${ }^{38}$

[A] block may not be marketable ... for several years. Creditors with special liquidity needs will therefore be undercompensated. Similarly, large creditors that originally sought a low-risk investment will find themselves with a risky common stock investment if they cannot quickly market the block of new common stock that they receive in reorganization .... Riskavoiding large creditors would thus be undercompensated if forced to receive common stock instead of the lower-risk debt that they would prefer to receive from the reorganized firm.

Roe, supra note 22, at 575-76.

${ }^{34}$ See Fortgang \& Mayer, supra note 2, at 7 (citing 12 U.S.C. \$\$ 24(7), 1843(a) \& (c)(2) (1988)); 12 C.F.R. $\$ \S 1.12,225.21$ (1990) (noting that nationally chartered banks and subsidiaries of bank holding companies must dispose of stock received in exchange for debt previously contracted within two years, although three one-year extensions may be obtained).

${ }^{35}$ When Japonica Partners traded the Allegheny International debt claims it had purchased for a $71 \%$ equity stake in the company, the company gained a solid debtto-equity ratio of $30 \%$. As a result, Standard \& Poor's raised the company's credit rating from $D$ to $B B$, "a higher upgrade than is typical of newly reorganized companies." Companies Emerging from Chapter 11 Will Have More Equity, CoRP. FINANCING WEEK, Oct. 8, 1990, at 1 (quoting Standard and Poor's upgrade statement).

${ }^{36}$ See 11 U.S.C. § 1126(e) (1988); supra note 11.

37 See 5 COLLIER ON BANKRUPTCY I 1126.05[1], at 1126-16 (L. King 15th ed. 1991) ("Good faith' ... was left undefined with the idea that the content of the phrase would be developed and construed in accordance with the cases as they arose.").

38 The statement reads:

Subsection (e) permits the court to designate for any class of claims or interests any person that has, with respect to that class, a conflict of interest that is of such nature as would justify exclusion of that person's claim or interest from the amounts and number specified in subsection (c) or (d). 
Determining how the good faith requirement affects a blocking minority and the relevance of the fact that the blocker is a claims purchaser requires reaching deeper into the legislative history. Section 1126(e) reads substantially like section 7-309(e) of the Report of the Commission on the Bankruptcy Laws of the United States. ${ }^{39}$ The note accompanying section 7-309 states that "[s]ubdivision (e) is derived from section 203 of the [Bankruptcy] Act and . . . Rule 10305(d). ${ }^{\text {40 }}$ Thus, interpretation of section 1126(e) requires an examination of the text and history of the superseded section 203 and Rule 10-305. ${ }^{41}$

A person might have such a conflict, for example, where he held a claim or interest in more than one class. Exclusion from one class for voting purposes would not require his exclusion from the other class as well. The result is to overrule cases such as Aladdin Hotel Corp. v. Bloom, 200 F.2d 627 (8th Cir. 1953), which, though not in the bankruptcy context, would appear to count votes for a reorganization plan motivated by an attempt to squeeze out a minority of a class. In that case, the conflict of interest of those voting for the plan was clear, but the court permitted the votes.

H.R. REP. No. 595, 95th Cong., 2d Sess. 411 (1977), reprinted in 1978 U.S. CoDE CONG. \& ADMIN. NEwS 5963, 6367. In Aladdin, equity holders acquired enough bonds ( $72 \%$ of those outstanding) to amend the terms of the mortgage securing the bonds. The amendment delayed maturity ten years. See Aladdin, 200 F.2d at 628.

Thus, the House Report statement addresses the case where a majority with an ulterior motive binds an unwilling minority. The statement, however, does not address the case where a minority blocks passage of a plan and does not mention how a claims purchaser is to be treated within the bad faith framework.

${ }^{39}$ Section 7-309(e) states: "Disqualification of Acceptance or Rejection. For the purpose of determining the requisite number of acceptances, the court may disqualify any acceptance or rejection of a plan or modification of a plan if such acceptance or rejection was not in good faith." REPORT OF THE COMMISSION ON THE BANKRUPTCY LAWS OF THE UNITED STATES, H.R. DOC. No. 137, 93rd Cong., 1st Sess., pt. II, at 250, reprinted in COLIIER ON BANKRUPTCY app. vol. 2, pt. I (L. King 15th ed. 1990).

${ }^{40} \mathrm{Id}$. at 251; see also 5 COLLIER ON BANRRUPTCY $\Upsilon$ 1126.05[1], at 1126-15 (L. King 15th ed. 1991) ("Section 1126(e) is derived from Chapter X Rule 10-305 of the Rules of Bankruptcy Procedure .... Chapter X Rule 10-305(d) was derived from Section 203 of the [Bankruptcy] Act . . . .7).

41 Subdivision (d) of Rule 10-505 states:

Disqualification of Acceptance or Rejection. For the purpose of determining the requisite number of acceptances, the court after hearing on notice to the creditor or stockholder may disqualify any acceptance or rejection of a plan or modification of a plan if such acceptance or rejection was not in good faith in the light of or irrespective of the time of the acquisition of the claim or stock by such creditor or stockholder.

13A COLLIER ON BANKRUPTCY I0-305.06, at 10-305-11 (J. Moore \& L. King 14th ed. 1977).

Section 203 states:

If the acceptance or failure to accept a plan by the holder of any claim or stock is not in good faith, in the light of or irrespective of the time of 
By discussing the Aladdin example, the statement accompanying section 1126(e) implies that the section was primarily aimed against the case of a majority which tries to "squeeze out a minority class." 42 By contrast, the history of section 203 and Rule 10-305(d) makes clear that their intent was to limit the veto power held by improperly motivated minorities. ${ }^{43}$ The section and rule offset the outcome of the prior leading case of Texas Hotel Securities Corp. v. Waco Development Co. ${ }^{44}$

In Texas Hotel, Conrad Hilton defaulted on the lease of a hotel in which he had invested substantial amounts of money making improvements. ${ }^{45}$ When the lessor subsequently declared bankruptcy, Hilton bought $33.5 \%$ of the lessor's outstanding mortgage bonds. Hilton rejected all reorganization plans in the hope of forcing a plan which would reinstate Hilton's management interest. ${ }^{46}$ The Fifth Circuit felt that Hilton was within his rights:

A debtor corporation ... is not guaranteed ... a right to a reorganization. It is given only the right to present a plan to its creditors and stockholders for their acceptance, with the advantage that the prescribed majorities in the classes affected can control unwilling minorities. No legal wrong is done the debtor if it cannot secure the required consents and is held to its original engagements, for that is but leaving to the creditors their original rights. ${ }^{47}$

The SEC disagreed, concerned that the Hilton group could "utilize their veto position to extort tribute from other creditors and stockholders as the price of their assent to a plan." ${ }^{48}$ Thus,

acquisition thereof, the judge may, after hearing upon notice, direct that such claim or stock be disqualified for the purpose of determining the requisite majority for the acceptance of a plan.

Id.

42 See H.R. REP. NO. 595, supra note 38 , at 6367.

43 See 13A COLLIER ON BANKRUPTCY I 10-305.06, at 10-305-12 (J. Moore \& L. King 14th ed. 1977) ("Section 203 and Rule 10-305 are intended to prevent creditors and stockholders by use of obstructive tactics or of hold-up techniques to exact for themselves advantages through acceptance or rejection of a plan, or to secure some preferential treatment such as management of the company for the price of their vote" (citing S.E.C. Commissioner (former Justice) Douglas in House Hearings Before the Committee on the Judiciary on H.R. 6439, 75th Cong., 1st Sess. 180, 182 (1937))).

1487 F.2d 395 (5th Cir. 1936), cert. denied, 300 U.S. 679 (1937).

45 See id. at 398-99.

16 See id. at 398.

${ }^{47}$ Id. at 399.

18 SECURTIIES AND EXCHANGE COMMISSION REPORT ON THE STUDY AND INVESTIGATION OF THE WORK, ACTIVITIES, PERSONNEL AND FunCtions OF PROTECTIVE AND 
examining to what extent the superseded section 203 and Rule 10305(d) limited the veto power of a minority should shed light on how section 1126(e) was intended to be applied.

\section{A. Guidance Given by Superseded Section 203 and Rule 10-305(d)}

Section 203 and Rule 10-305(d) made specific reference to trading claims, ${ }^{49}$ unlike section $1126(e) .{ }^{50}$ The phrasing suggests that the court has considerable discretion in deciding how much importance, if any, to assign to the timing and pricing of the purchases:

The Rule, as well as $\S 203$, does not forbid trading or transfer of claims and interests, before or during reorganization, but expressly makes time of acquisition a factor to be considered in determining good faith. But time of acquisition is not controlling. ... Likewise, the price paid by the assignee or seller of claims or interests is an element to be considered, but not necessarily controlling. In the absence of fraud, misrepresentation, overreaching or violation of fiduciary obligation calling for the exercise of the equitable power of the court, the prices paid by security holders for their securities in no wise affects the measure of their participation in the voting. ${ }^{51}$

The most specific guidance given the court on the intent of the section and rule was that they were designed to discourage the situation,

where a fellow goes out and buys securities at a default price and then sits back in a nuisance or strategic position and seeks to capitalize on that. It also covers the situation where he does not

REORGANIZATION COMMTTEES 1936-40, pt. VIII, at 121 (1940), quoted in 6 CollIER ON BANKRUPTCY pt. 2, I 9.21, at 1674 (J. Moore \& L. King 14th ed. 1978).

${ }^{49}$ See supra note 41 .

50 See supra note 11.

51 13A COLLIER ON BANKRUPTCY \ 10-305.06, at 10-305-13 (J. Moore \& L. King 14th ed. 1977) (footnotes omitted) (citing In re Lorraine Castle Apartments Bldg. Corp. Inc., 149 F.2d 55 (7th Cir.), cert. denied, 326 U.S. 728 (1945); In re P-R Holding Corp., 147 F.2d 895 (2d Cir. 1945); Mokava Corp. v. Dolan, 147 F.2d 340 (2d Cir. 1945); In re Pine Hill Collieries Co., 46 F. Supp. 669 (E.D. Pa. 1942)); see also 5 COLLIER ON BANKRUPTCY 1 1126.05[2], at 1126-18 (L. King 15th ed. 1991) (noting that "the existence of trading in securities of the debtor prior to the commencement of the case generally will not provide a basis for disqualifying the claim or interest of a purchaser acquiring such securities so long as the purchase and sale complied with applicable non-bankruptcy law"). Collier's conclusion is put in doubt by In re Allegheny Int'l, Inc., 118 Bankr. 282 (Bankr. W.D. Pa. 1990). See infra notes 104-108 and accompanying text. 
buy at a default price, but nevertheless is working a hold-up scheme on those who are trying to get these securities in during reorganization. ${ }^{52}$

Courts face the challenge of reconciling the majority's right to overcome a "nuisance" with the minority's right to appraise the proposed plan and cast its vote in its own self interest. ${ }^{53}$ The good faith rule was not intended to stop creditors from voting selfishly. ${ }^{54}$ Each voter has the right to judge the plan offered according to his own economic position and personal assessments. Early on, courts recognized the inherent conflict between the right to vote selfishly and the duty not to be a nuisance:

[Section 203] prescribes a standard of conduct defined by the elusive term 'good faith', which must be met under pain of disqualification. The test is plainly to be sought in the motives of the holder of the claims. The Securities and Exchange Commission suggests in its brief that if assent is withheld to serve some ulterior selfish purpose, good faith is wanting. If the emphasis be placed on 'ulterior' rather than 'selfish' this seems to be as practical a test as could be found. What is selfishness from the standpoint of those who derive no benefit from conduct under scrutiny often becomes enlightened self-interest if viewed from the standpoint of those who gain by it. If a selfish motive were sufficient to condemn reorganization policies of interested parties, very few, if any, would pass muster. On the other hand, pure malice, 'strikes' and blackmail, and the purpose to destroy an enterprise in order to advance the interests of a competing business, all plainly constituting bad faith, are motives which may be accurately described as ulterior. ${ }^{55}$

52 House Hearings Before the Committee on the Judiciary on H.R. 6439, 75th Cong., 1st Sess. 183-84 (1937) (statement of Commissioner Douglas), quoted in 6 ColLIER ON BANRRUPTCY pt. 2, I 9.21, at 1675 (J. Moore \& L. King 14th ed. 1978).

53 See 6 CollLER ON BANKRUPTCY pt. 2, 19.21 , at 1677 (J. Moore \& L. King 14th ed. 1978) (noting that "democratization" of the reorganization process was a major goal of the Bankruptcy Act).

${ }^{54}$ See id. at 1676 (citing House Hearings Before the Committee on the Judiciary on H.R. 6439, 75th Cong., 1st Sess. 180-81 (1937) (statement of Commissioner Douglas)); Teton, Reorganization Revised, 48 YALE L.J. 573, 601-02 (1939).

${ }^{55}$ In re Pine Hill Collieries Co., 46 F. Supp. 669, 671 (E.D. Pa. 1942); see also Kremer v. Clarke (In re Frank Fehr Brewing Co.), 268 F.2d 170, 180 (6th Cir. 1959), cert. denied, 362 U.S. 963, reh'g denied, 363 U.S. 817 (1960) ("Self interest is not the same as ulterior motive or bad faith. The purchase of creditors' claims for the purpose of securing approval of a plan which the purchaser considers to be in his best interests does not of itself amount to bad faith so as to invalidate the plan."). 
Further, courts which construed section 203 found no good faith problem with amassing sufficient negative votes to block a plan. "Such minority may choose to use the veto power, which the law thus allows it to obtain, rather than go to the expense of producing testimony or attempting to persuade the other interests and the Court that the plan is not a good one. ${ }^{1156}$

\section{B. Judicially Developed Frameworks for Application of the Good Faith Standard}

There are two routes by which a claims purchaser with a minority blocking position enters the realm of bad faith. These routes are developed in Young $v$. Higbee $\mathrm{Co}^{57}$ and In re P-R Holding Corp. ${ }^{58}$

In Young v. Higbee Co., the Supreme Court cast some light on where the dividing line is between a bad faith hold-up and a legitimate self-interested veto:

[Texas Hotel] held that a creditor could not be denied the privilege of voting on a reorganization plan, .... although he bought the votes for the purpose of preventing confirmation unless certain demands of his should be met. The hearings make clear the purpose of the Committee to pass legislation which would bar creditors from a vote who were prompted by such a purpose. ${ }^{59}$

In Young, two preferred shareholders filed suit to subordinate a large unsecured loan purchased by insiders of the bankrupt. ${ }^{60}$ The two preferred shareholders subsequently sold their stock to the insiders being sued for $\$ 115,000$ when the stock had a market value of $\$ 17,000 .^{61}$ The lawsuit was thereby extinguished, to the detriment of all other preferred shareholders. The Supreme Court found the selling preferred shareholders to be in bad faith because they took "more than the ratable equivalent of their proportionate

${ }^{56}$ In re Pine Hilh 46 F. Supp. at 672; see also In re P-R Holding Corp., 147 F.2d 895, 897 (2d Cir. 1945) ("The mere fact that a purchase of creditors' interests is for the purpose of securing the approval or rejection of a plan does not of itself amount to 'bad faith."); Mokava Corp. v. Dolan, 147 F.2d 340, 344 (2d Cir. 1945) (holding that one who purchased claims in a particular class in order to frustrate the acceptance of that class was not acting in bad faith).
37324 U.S. 204 (1945).
58147 F.2d 895 (2d Cir. 1945).
59324 U.S. at 211 n.10 (citation omitted).
${ }^{60} \mathrm{See} i d$. at 206.
${ }^{61}$ See id. at 207. 
part of the bankrupt assets. ${ }^{n 2}$ The Court's holding and its statement regarding Texas Hotel suggest that bad faith occurs when a claimant demands better treatment than the rest of his class will receive. ${ }^{63}$

By distinction, one who vetoes a plan to improve his own position and the positions of all others similarly situated presumably should not be held in bad faith. ${ }^{64}$ The premise that a claims purchaser will be found to have voted in good faith as long as he endeavors to improve the return for all other claimants in his class puts great importance on the classification scheme. ${ }^{65}$ This applica-

62 Id. at 211.

${ }^{63}$ In Texas Hotel Hilton was holding out for a management interest in the reorganized entity. See supra note 46 and accompanying text; see also In re P-R Holding Corp., 147 F.2d 895, 898 (2d Cir. 1945) (finding bad faith where plan proponents purchased the claims of objectors for 50 cents on the dollar in cash when plan proposed to pay others in class 50 cents on the dollar in securities); In re Fuller Cleaning \& Dyeing Co., 118 F.2d 978, 979 (6th Cir. 1941) (finding bad faith where plan proponents agreed to buy certain but not all bonds for $90 \%$ of face value should the plan be approved, thus inducing key acceptances); Fortgang \& Mayer, supra note 2, at 96 ('[T]he Act did not, and the Code does not, allow 'greenmail.' That is, an investor with a blocking position (a 'blocker') cannot capitalize on that position to receive treatment different from the rest of the creditors or shareholders in the blocker's class.").

The finding in $P-R$ Holding raises interesting questions which it may not have intended. The decision stated "there is 'bad faith' when those purchases result in a discrimination in favor of the creditors selling their interests." P-R Holding, 147 F.2d at 897. The court disapproves of claimants who object to the plan, sell, and thereby fare better than the claimants who accept. Presumably this transaction would not have been in bad faith had the cash payment on sale been something less than $50 \%$, the amount accepting creditors received in securities, which are less desirable than cash. The question of how much less than $50 \%$ makes this transaction acceptable is left open. See 6 CoLLIER ON BANKRUPTCY pt. 2, I 9.21, at 1682 n.50 (J. Moore \& L. King 14th ed. 1978). Further, $P-R$ Holding leaves open the good faith of a transaction in which a plan proponent buys the objectors' claims at a price which appears to be a discount but which ends up being a premium because the deteriorating finances of the debtor do not allow payout at the level that was anticipated in the original plan.

64 See supra notes 55-56 and accompanying text (discussing Pine Hill); In re RadioKeith-Orpheum Corp., 106 F.2d 22 (2d Cir.), cert. denied, 308 U.S. 622 (1939); In re Michigan-Ohio Bldg. Corp., 97 F.2d 845 (7th Cir. 1938).

${ }^{65}$ The debtor, in deciding the class scheme may try to gerrymander the vote in order to dilute the impact of unfriendly claimants. See, e.g., Roe, The Voting Prohibition in Bond Workouts, 97 YALE L.J. 232, 267 (1987) ("[B]ondholders cannot be sure of how their claims will be classified. They have to fight to avoid classification with other creditors, which would dilute the bondholders' vote."); see also In re U.S. Truck Co., 800 F.2d 581, 584 (6th Cir. 1986) (allowing class gerrymander even though debtor admitted and the court was aware that the purpose of the segregation was to ensure the approval of at least one impaired class). Compare 3 NORTON BANRRUPTCY LAW AND PRACTICE $\$ 60.05$, at 7 (1986) ("Unsecured claims will, generally speaking, comprise one class, whether trade, tort, publicly held debt or a deficiency of a 
tion of the good faith rule leaves the claims purchaser ample opportunity for profit as long as the others in his class share in the gains. Alternatively, the claims purchaser can avoid sharing the gains by buying all of the claims in his class, should he have the resources and find willing sellers. ${ }^{66}$

In re P-R Holding Corp. ${ }^{67}$ develops the second route by which a claims purchaser with a minority blocking position enters the realm of bad faith:

The mere fact that a purchase of creditors' interests is for the purpose of securing the approval or rejection of a plan does not of itself amount to 'bad faith.' When that purchase is in aid of an interest other than an interest as a creditor, such purchases may amount to 'bad faith' under section $203 \ldots .68$

The language "an interest other than an interest as a creditor" sheds some light on the distinction between an ulterior motive, which is bad faith, and a simply selfish motive, which while not commendable, is not bad faith. ${ }^{69}$ Presumably, the interest of a creditor as creditor is to maximize the return on the debt he is owed. Given its most permissive interpretation, this test would only find bad faith in the motives discussed as ulterior in Pine Hill. ${ }^{70}$ Given its least permissive interpretation, this test would find bad faith in any vote which had as its motive the furtherance of a relationship with the reorganized entity. ${ }^{71}$

secured creditor.") with 5 COLLIER ON BANKRUPTCY 1122.03 [1][b], at 1122-7 (L. King 15th ed. 1991) (noting "that the Code does not require that all claims that are substantially similar be placed in the same class").

${ }^{66}$ See Mokava Corp. v. Dolan, 147 F.2d 340, 344 (2d Cir. 1945) (holding that the purchaser of an entire class of mortgage bonds had the right to vote those claims against the reorganization plan, thereby blocking confirmation, even though the original holders had voted in favor of the plan before selling).

67147 F.2d 895 (2d Cir. 1945).

${ }^{68} I d$. at 897. Additionally, the court in $P-R$ Holding found bad faith on the discrimination theory described supra notes 57-66 and accompanying text.

${ }^{69}$ See supra notes 37 \& 54 and accompanying text.

${ }^{70}$ See supra note 55 and accompanying text.

71 For example, the pursuit of a relationship as stockholder, manager, supplier, employee, lender, or favored customer would lead to a finding of bad faith. 


\section{Effect of Finding of Bad Faith in Voting}

If the court does decide that the claims purchaser has cast his votes in bad faith, the court is limited in the remedy it can apply. "The Code does not give the court power under section 1126(e) to reduce the amount of claims or interests for voting purposes but only permits the court to disqualify in toto an acceptance or rejection of the claim or interest of a particular entity."72 Thus, votes cast in bad faith are simply not counted at all. The claim purchaser's right to collect his pro rata share of whatever payout is approved is not impaired.

One should note that disqualification of his votes does not leave the claims purchaser totally without influence over the outcome of the vote. When the purchaser's votes are found to be in bad faith, his claims have no voting rights, so the votes of the claim holders who sold to the purchaser are not reinstated. ${ }^{73}$ Thus, the claims purchaser who wishes to block a plan need only buy the claims of holders who would otherwise accept the plan to retire those acceptances. Fewer rejection votes will then be necessary to block confirmation of the plan. ${ }^{74}$

725 CoLLIER ON BANKRUPTCY I 1126.05[2], at 1126-18 (L. King 15th ed. 1991). The courts were limited to the same remedy under section 203 and Rule 10-305(d). See 6 COLLIER ON BANRRUPTCY pt. 2, I 9.21, at 1681 (J. Moore \& L. King 14th ed. 1978) (citing H.R. REP. NO. 1409, 75th Cong., 1st Sess. 47 (1937)).

73 See, e.g., P-R Holding, $147 \mathrm{~F} .2 \mathrm{~d}$ at 898 (refusing to reinstate the votes of former holders who sold to bad faith purchasers). The $P-R$ Holding court confirmed the reorganization plan even though the claims purchaser's acceptance votes were disqualified because there were still enough votes for acceptance. The court was aware that all of the selling claimants had voted to reject, and that those rejections would have been sufficient to block the plan. However, the court refused to reinstate the negative votes of the selling claimants: "To permit the votes of former certificate holders to be counted would be to permit those with no interest in the plan to control its acceptance." Id.

74 To illustrate, suppose that the debtor has issued $\$ 100$ face amount in bonds. Before the claims purchaser enters the picture, holders of $\$ 74$ face amount of the bonds approve of the plan while holders of $\$ 26$ face amount of the bonds disapprove. Clearly, the debtor has the two-thirds face amount approval necessary to confirm a plan. See supra note 10 and accompanying text. Assume that before the final vote, a claims purchaser desiring to block confirmation buys $\$ 25$ face amount of bonds from holders who would otherwise accept the plan. The vote would now be $49 \%$ accepting and $51 \%$ rejecting. Further assume that the claims purchaser is found to have voted in bad faith and his votes are disqualified. The vote is now $\$ 49$ accepting and $\$ 26$ rejecting with a total pool of $\$ 75$ voting. The corresponding percentages are $65.3 \%$ accepting and $34.7 \%$ rejecting, meaning plan confirmation is blocked even though the claims purchaser was not permitted to participate in the vote. 
This strategy is especially potent when the class of debt claims involved is widely held and solicitation of votes is therefore difficult. Section 1126(c) requires two-thirds face amount approval of those holders who actually vote. ${ }^{75}$ By buying the claims of holders who are likely to vote and likely to accept, ${ }^{76}$ the purchaser can fashion a blocking position out of a group of rejecting voters who hold a relatively small percentage of the total outstanding claims in the class. ${ }^{77}$

\section{RECENT APPLICATIONS OF GOOD FATTH IN VOTING Rules to Glaims Purchasers}

Courts which have been called upon to judge the good faith of a claims purchaser under section 1126(e) of the Bankruptcy Code have all purported to follow the two models developed under the Bankruptcy Act. ${ }^{78}$ However, these recent decisions applying the

75 The statute specifically states that a plan is accepted by a class of claims when "at least two-thirds in amount . . . of the allowed claims of such class . . . have accepted or rejected the plan." 11 U.S.C. $\$ 1126$ (c) (1988) (emphasis added). See 5 CoLLIER ON BANKRUPTCY 1126.03 , at 1126-12 (L. King 15th ed. 1991) (stating that "only claims actually voted count in determining whether the requisite majorities in number and amount are met").

${ }^{76}$ For example, large or institutional claim holders.

77 To illustrate, suppose that a debtor has issued $\$ 100$ face amount in bonds. Suppose further that the claim purchaser's $\$ 25$ face amount claim has been disqualified and that holders of $\$ 45$ face amount have not returned vote solicitations. In this case, only the votes of holders of $\$ 30$ face amount of claims are counted. Rejection votes by holders of $\$ 11$ face amount of claims, $36.7 \%$ of those voting but only $11 \%$ of the total allowed clairns in the class, are enough to block confirmation of the plan. See, e.g., In re Allegheny Int'l, Inc., 118 Bankr. 282, 28'7 (Bankr. W.D. Pa. 1990) ("Although Japonica purchased less than $1 / 3$ of the claims in Class 4.AI.2, its negative votes were sufficient to defeat the debtor's plan in that class because of the large number of claims in Class 4.AI.2 that did not vote.").

78 These models are: (1) the differential treatment of claims within the same class model developed in Young v. Higbee Co., 324 U.S. 204 (1945), discussed supra notes 57-66 and accompanying text, and (2) the ulterior motive model developed in In re P-R Holding Corp., 147 F.2d 895 (2d Cir. 1945), discussed supra notes 67-71 and accompanying text. See, e.g., In re Federal Support Co., 859 F.2d 17, 19 (4th Cir. 1988) ("It is well settled . . . that good faith in casting a vote does not require of the creditor a selfless disinterest. Each creditor is expected to cast his vote in accordance with his perception of his own self-interest, but he may not act with an ulterior or coercive purpose." (citing Young, 324 U.S. at 211 and P-R Holding, 147 F.2d at 897)); Allegheny, 118 Bankr. at 288-89 (same); In re Gilbert, 104 Bankr. 206, 215-16 (Bankr. W.D. Mo. 1989) (same); In re MacLeod Co., 63 Bankr. 654, 655 (Bankr. S.D. Ohio 1986) (same); In re Featherworks Corp., 36 Bankr. 460, 463 (E.D.N.Y. 1984) (finding bad faith where a creditor was paid outside of the bankruptcy plan to change its vote); In re Landau Boat Co., 8 Bankr. 432, 434 (Bankr. W.D. Mo. 1981) (citing Young, 324 U.S. at 210-11). 
models leave difficult questions regarding the permissiveness of the good faith standard of section 1126(e).

\section{A. Decisions Suggesting a More Permissive Standard}

One set of decisions gives the claims purchaser wide latitude to influence the reorganization process. In re Gilbert ${ }^{79}$ allowed a creditor who held a claim in class III and who was an associate of the debtor to buy two claims in class $\mathrm{X}$ in order to control the vote of the latter class. ${ }^{80}$ The judge was not troubled by the admissions that the creditor made the purchases to protect his existing claim in the other class ${ }^{81}$ and that the purchases were made at deep discounts. ${ }^{82}$ The decision stated "[a]s long as a creditor acts to preserve what he reasonably perceives as his fair share of the debtor's estate, bad faith will not be attributed to his purchase of claims to control a class vote. ${ }^{n 83}$ Thus, voting a claim in one class in support of a claim in another class is not an ulterior motive; rather, the strategy legitimately furthers the creditor's self-interest. ${ }^{84}$

Gilbert concludes that purchasing claims to control the vote in one class for the benefit of a claim in another class is not a purchase in aid of "an interest other than an interest as a creditor" as developed by $P-R$ Holding. ${ }^{85}$ Presumably, Gilbert reaches this conclusion because the purchaser was a creditor in both classes. ${ }^{86}$ This outcome greatly enhances the strategic options open to the claims purchaser. Under Gilbert the claims purchaser can find a

79104 Bankr. 206 (Bankr. W.D. Mo. 1989).

${ }^{80} \mathrm{See}$ id. at 208, 217.

${ }^{81}$ See id. at 216 ('[Creditor's] testimony was that the sole purpose behind his purchase and subsequent vote of the [purchased] claim was to protect his other claims against Debtors' estate.").

82 The creditor purchased claims of $\$ 169,571$ and $\$ 143,020$ for $\$ 21,500$ and $\$ 5,000$, respectively. The plan the creditor was helping to get confirmed called for the creditor to be paid only $\$ 4,200$ for the $\$ 143,020$ claim, further evidencing that the claim was purchased for a purpose other than pure speculative profit. See id. at 208.

83 Id. at 217.

84 See id. at 216 ("Part of his self-interest lies in protecting his $\$ 15,000.00$ claim classified in [Class III].").

${ }^{85}$ See supra notes 67-68 and accompanying text.

${ }^{86} \mathrm{Had}$ the claims been purchased to control the vote of one class in order to aid the purchaser's interest as a stockholder, the case would very closely resemble the situation which the Eighth Circuit approved of in Aladdin Hotel Corp. v. Bloom, 200 F.2d 627 (8th Cir. 1953), and which the legislative statement accompanying \$ 1126(e) expressly disapproved. See supra note 38 and accompanying text. 
bankruptcy situation and target two classes, A and B, one for its profit potential and the other for its strategic voting position. If a court held, contrary to Gilbert, that voting claims in one class in support of claims in another class is bad faith, ${ }^{87}$ the claims purchaser would instead have to find a bankruptcy situation in which a single class offers both sufficient profit and voting power. The latter bankruptcy situation will be more difficult to find.

Another area in which courts have been permissive in their application of the section $1126(\mathrm{e})$ good faith standard involves the power of a claimant who is being sued by the debtor to veto the debtor's reorganization plan. In re Landau Boat Co ${ }^{88}$ allowed a claimant who was being sued by the debtor in antitrust to vote to reject a plan which would pay $10 \%$ of claims. ${ }^{89}$ The rejection would force the liquidation of the debtor, yielding the creditors nothing. The debtor charged that the claimant voted with the ulterior motive of weakening the prosecution of the antitrust suit and was thus in bad faith under section 1126(e). ${ }^{90}$ The court refused to find bad faith. The court speculated that completely writing off the debt may have been more valuable to the claimant than a $10 \%$ payment and thus the debtor's conclusion of an ulterior motive was not "inescapable." The court also found that the claimant was under no obligation to explain its vote. ${ }^{92}$ Landau Boat suggests that the objector carries a heavy burden of showing bad faith as the result of an ulterior motive. A possible legitimate motive made a present improper motive uncompelling. ${ }^{93}$

${ }^{87}$ See infra notes 116-19 and accompanying text (discussing In re Allegheny Int'l, Inc., 118 Bankr. 282 (Bankr. W.D. Pa. 1990)).

888 Bankr. 432 (Bankr. W.D. Mo. 1981).

${ }^{89}$ See id. at 433.

90 See id.

91 Id. at 435.

92 See id. (stating that "[a]lthough there are many reasons why an unsecured creditor would reject a plan paying it some money, [claimant] has offered no explanation for its rejection nor is it obligated to do so").

${ }_{93}$ See In re Federal Support Co., 859 F.2d 17, 20 (4th Cir. 1988) (holding that a claimant which was the defendant in debtor's antitrust suit was not in bad faith in vetoing debtor's plan of reorganization where the claim was the debtor's sole remaining asset). 


\section{B. Decisions Suggesting a Less Permissive Standard}

Another set of decisions limits the claims purchaser's influence over the reorganization process. In re MacLeod Co. ${ }^{94}$ addressed the relatively easy case where the claimants who sought to block approval of the debtor's plan directly competed with the debtor through a company that the claimants began while employees of the debtor. ${ }^{95}$ Citing $P-R$ Holding ${ }^{96}$ and In re Pine Hill Collieries Co., ${ }^{97}$ the court found the votes to be cast in bad faith as the claimants had the ulterior motive of increasing their own business at the expense of a liquidated debtor. ${ }^{98}$

In re Allegheny International, Inc. ${ }^{99}$ is arguably the most important of the cases construing the good faith requirement of section 1126(e) to date. The forty-six page decision was very recent, involved a large debtor, and received an enormous amount of press. ${ }^{100}$ In Allegheny, an investment firm called Japonica Partners ("Japonica") purchased enough claims in two classes to exercise a blocking position in each. ${ }^{101}$ Japonica subsequently offered its own reorganization plan and proceeded to buy more claims in an effort to secure its approval. ${ }^{102}$ Japonica's clear intention was to hold as much equity in the reorganized debtor as possible. ${ }^{103}$ When neither the debtor's plan nor Japonica's plan won approval, the court found that Japonica's votes were in bad faith and confirmed the debtor's plan. ${ }^{104}$

After noting that there were few precedents, and none controlling, concerning section 1126(e), the court undertook a

9463 Bankr. 654 (Bankr. S.D. Ohio 1986).

95 See id. at 654-55.

${ }^{96}$ See supra note 67 and accompanying text.

9746 F. Supp. 669 (E.D. Pa. 1942); see supra note 55 and accompanying text.

${ }^{98}$ MacLeod, 63 Bankr. at 655-56.

99118 Bankr. 282 (Bankr. W.D. Pa. 1990).

${ }^{100}$ Allegheny Int'l, Inc. (renamed Sunbeam-Oster since emerging from bankruptcy in August 1990) has over $\$ 1$ billion in annual revenues. For popular press articles dealing with the relevant aspects of the bankruptcy, see Franklin, Battle for Allegheny: Judge Warns Investors Not to Follow Japonica's Tactics, N.Y.L.J., Oct. 11, 1990, at 5, col. 2.; Schifrin, supra note 3, at 74; Judge Clears Allegheny Deal N.Y. Times, July 17, 1990, at D5, col. 5 .

${ }^{101}$ See Allegheny, 118 Bankr. at 286-87.

102 See id. at 295-96.

103 See id. at 286.

${ }^{104}$ See id. at $319-20$. 
considered review of section 203 of the Bankruptcy Act and the cases thereunder. ${ }^{105}$ Judge Cosetti held that:

\begin{abstract}
Although [Japonica] testified that [it] voted against the plan for economic reasons, the court does not find the economic reasons offered by Japonica creditable. We find that Japonica acted 'in aid of an interest other than an interest as a creditor...' In re $P-R$ Holding, 147 F.2d at 897 . The overriding fact that causes this court to reach this conclusion is that Japonica chose to buy claims which gave it unique control over the debtor and the process. With one minor exception, Japonica purchased its claims-and became a creditor-after the debtor's disclosure statement was approved. Japonica knew what it was getting into when it purchased its claims. Japonica is a voluntary claimant. If Japonica was unsatisfied by the proposed distribution, it had the option of not becoming a creditor. ${ }^{106}$
\end{abstract}

The court's statements imply that actually using a blocking position, acquired through purchasing claims, is per se bad faith: "[i]f, as in the instant case, an outsider to the process can purchase a blocking position, those [other] creditors and interest holders are disenfranchised. Moreover, Japonica, who chose to become a creditor, should not have veto control over the reorganization process." 107

Allegheny creates the "poison pill" of bankruptcy. According to Allegheny, a claims purchaser who enters the reorganization process at an advanced stage will have his votes disqualified if he crosses the threshold of ownership of one-third of a class and tries to use the accompanying veto power to improve the payout to his class.

Japonica's purpose in exercising its veto was to gain control of the debtor. The question is open to debate as to whether this purpose is ulterior and therefore bad faith or, on the other hand, is a legitimate self-interested attempt to maximize returns by taking equity from a debtor who could not afford to pay cash. ${ }^{108}$ How-

105 See id. at 287-89.

106 Id. at 289.

${ }^{107}$ Id. at 290.

108 This question is especially difficult in the context of Allegheny because two separate good faith issues unfortunately become blended. Japonica proposed its own reorganization plan and tried to win its approval by buying enough claims to compose the necessary majorities. See id. at 297 . Judge Cosetti found that " $[t]$ he control tactic of this tender offer itself was extremely inequitable. It placed unfair choices on the debenture holders. It constitutes bad faith." Id. at 296. The court also held that Japonica acquired inside information in the course of the due diligence it performed in connection with its proposed plan. This information gave Japonica status as a fiduciary. See id. 
ever, if the "overriding" consideration is that the claims purchaser is a voluntary creditor, an "outsider," the motive question will not be adequately addressed. ${ }^{109}$ Even the claims purchaser who seeks only an increased cash payout for his claims and tries to gain influence through the power of the vote will fall prey to the poison pill. The result is that the claims purchaser and the original claim holder are judged by different standards. The reasons for the double standard are not at all clear given that the claims purchaser may serve a beneficial purpose in the reorganization process. ${ }^{110}$

Judge Cosetti was concerned that a claims purchaser with a blocking position "disenfranchises" the other claim holders, contrary to congressional intent. ${ }^{111}$ To the contrary, the twothirds in amount and one-half in number requirements for voting detailed in section $1126(c)^{112}$ establish a delicate balance in the negotiating power of the parties to a reorganization. The two-thirds rule gives a substantial minority a substantial voice to use in its selfinterest. The poison pill upsets this balance. The debtor in possession has considerable power by virtue of its right to operate the business ${ }^{113}$ and its right to the exclusivity period. ${ }^{114} \mathrm{~A}$ claims purchaser with the resources to amass a blocking position and the expertise to use that position to negotiate a more equitable plan may be management's only serious rival.

Japonica's bad faith actions in trying to secure passage of its own plan should not mean that Japonica acted in bad faith in vetoing the debtor's plan. The plans, and the votes on them, were separate and thus required separate good faith inquiries. It is possible, however, that the court found Japonica's actions in securing a majority for its plan so egregious that the court, perhaps unnecessarily, condemned Japonica's less offensive action of voting its minority blocking position against the debtor's plan.

109 Judge Cosetti gave great weight to both the timing and prices of the purchases made by Japonica. See id. at 286-87 and 289-90. Though section 1126(e) makes no mention of timing or price paid, section 203 of the Bankruptcy Act allowed a court discretion to assign them weight or not. See supra note 51 and accompanying text. The majority of the cases decided under the Bankruptcy Act, however, assign little importance to the issues of timing and price. See supra note 51. tion).

${ }^{110}$ See supra notes 24-35 (identifying positive aspects of claim purchaser participa-

111 Allegheny, 118 Bankr. at 290. Other judges under similar circumstances have not shared this concern. See supra note 56 and accompanying text.

112 See supra note 10 and accompanying text.

113 The debtor in possession can use the property of the estate and enter into transactions in the ordinary course of business without notice or a hearing. See 11 U.S.C. § 363(c)(1) (1988).

114 Only the debtor may file a reorganization plan in the first 120 days after the bankruptcy petition is filed. The bankruptcy court can, and often does, extend the period of exclusivity. See 11 U.S.C. \$ 1121(b) \& (d) (1988). 
A final point to be made regarding Allegheny is that it casts serious doubt on the vitality of the permissive stand taken on dual class voting in In re Gilbert. ${ }^{115}$ Japonica purchased enough claims in class 4 to block the plan's acceptance and support the blocking position Japonica already held in class 2.116 Unfortunately, the two classes held opposite positions with respect to the outcome of pending litigation. ${ }^{117}$ The Allegheny court stopped just short of finding the dual class voting strategy to be in bad faith. ${ }^{118}$ Under the less permissive approach, a creditor casting its class $B$ votes must vote in light of its interests as a member of class $B$ and not in aid of its interest as a creditor in class $A$. If a claims purchaser were to vote both his class $A$ votes and class $B$ votes in aid of his interest in class A, logic suggests that only the class $B$ votes should be disqualified as in bad faith. The class $A$ votes were voted only in aid of class A interests. Therefore, even under the less permissive approach, the claims purchaser should be left with his original blocking position in class A. In Allegheny, Japonica's votes in all classes were disqualified, contrary to the logic stated above. ${ }^{119}$

\section{Changing Market Conditions}

At least two significant recent developments have received insufficient notice in the debate surrounding trading claims. These developments impact how permissive the good faith standard should be.

One development is the increasing sophistication of the players and the mechanisms involved in reorganization. The sophistication is the result of the increased volume of bankruptcy filings and the experience gained in dealing with them. Claim purchasers find profit in distressed claims because they trade at a discount to their "true" or "realizable" value. ${ }^{120}$ Evidence suggests, however, that

${ }^{115} 104$ Bankr. 206 (Bankr. W.D. Mo. 1989); see supra notes 80-87 and accompanying text.

${ }_{116}$ See Allegheny, 118 Bankr. at 290.

117 See id. at 287 .

118 See id. at 290 ("The court is hard pressed to characterize Japonica's actions as merely furthering their own economic interests.").

119 See id.

${ }^{120}$ See generally Kraakman, Taking Discounts Seriously: The Implications of "Discounted" Share Prices As An Acquisition Motive, 88 ColuM. L. REV. 891 (1988). Professor Kraakman states:

[T] here is a growing theoretical literature on 'mispricing' behavior, which argues that uninformed traders may introduce persistent biases or 
the discounts are becoming rarer. ${ }^{121}$ The increased investment in vulture funds accounts for part of the erosion in discounts since increased demand bids up the prices of the claims. Sellers who are better informed about the meaning and consequences of a bankruptcy filing account for the remainder of the erosion of discounts. Traders selling on organized markets are less likely to touch off the uninformed "noise" or "panic" trading which results in mispricing. ${ }^{122}$ Selling into an unorganized market, institutional lenders with a long-time relationship with the debtor are better able to apply their knowledge of the debtor's finances to the bankruptcy context. Similarly, trade claimants are better able to apply their knowledge of the debtor's industry and its future to the bankruptcy context. An institutional lender or trade claimant who has failed to become more sophisticated with respect to bankruptcy may likely still benefit by simply asking the prices received by more sophisticated players involved with the same debtor.

The increased sophistication of claim sellers and the concomitant erosion of the discount at which claims sell cast doubt on the assertion that claims purchasers take advantage of sellers. ${ }^{123}$ Sophisticated claim holders benefit from a ready market for their claims. By selling, claim holders who are not in the business of pressing claims against distressed debtors can capture a portion of the value added by buyers who are in the business of pressing such claims. If buyers are permitted to exercise a minority (34\%) veto,

cumulative noise into share prices or that speculative trading might lead to positive or negative price 'bubbles.' ... . [S]ome commentators suggest that noise trading further distorts share prices by encouraging informed traders to speculate on noise and by imposing 'noise trader risk' on all traders in a noisy market. Finally, noise theorists find evidence of mispricing in the long-term price behavior of both individual firms and the entire market.

Id. at 899-90 (footnotes omitted).

${ }^{121}$ See, e.g., 'Debt Raiders,' supra note 1, at $\mathrm{D} 8$, col. 2 ("Indeed, there has recently been such a surge of interest in distressed debt that some longtime bankruptcy investors are complaining that they can't make any real money."). Situations in which experienced claims purchasers have lost large portions of their investments also serve as evidence of the evaporation of discounts. For example, Balfour acknowledged losing $\$ 13.5$ million on its investment of $\$ 50$ million in Global Marine. See id. Amroc Investments L.P. has seen its \$2.1 million investment in trade claims against Eastern Air Lines purchased from Marriot lose almost all of its value. See In re Ionosphere Clubs, Inc., 119 Bankr. 440, 442 (Bankr. S.D.N.Y. 1990). Bankruptcy specialist Stan Phelps paid an average of 15 cents on the dollar for MGF Oil bonds, which are now worth less than one cent each. See Schifrin, supra note 3, at 77.

122 See supra note 120.

123 See supra note 21 and accompanying text. 
the value added to the claims they purchase will be greater and the sophisticated seller will, in turn, be able to negotiate a higher price. Furthermore, a ready market for claims makes people more willing to do business with a distressed but not yet bankrupt debtor. The ability to sell claims quickly at a higher price makes the consequences of the debtor's failure less costly. The institutional lender or trade creditor can recover more money and more quickly channel it back into its own field of business.

The second development receiving insufficient attention is the changing reasons why many large debtors enter bankruptcy. Until only a few years ago, most of the large companies which entered bankruptcy did so because of serious operational or product problems. ${ }^{124}$ Many of the large bankruptcy filings today, however, are not the result of operational decline but rather the result of excessive debt in the capital structure ${ }^{125}$ or of liabilities stemming from past product problems. ${ }^{126}$

The changing reasons for filing bankruptcy in turn alter the dynamic of the reorganization process. When a debtor is in operational decline, the bankruptcy is primarily a battle among creditors to split up the losses. When a debtor is operationally healthy but financially sick, the reorganization is more of a battle between creditors as a group and the debtor to decide who will bear the losses. The debtor's management, even though it has the fiduciary responsibility of a trustee, increasingly champions the debtor's interests at the expense of the creditors because of management's interest in being employed by the reorganized entity. ${ }^{127}$ Management has tremendous power in the reorgani-

124 See Roe, supra note 65, at 273 n.127 ("Bankruptcy is usually a reflection of operational decline. The frictions of bankruptcy exacerbate the decline, but most observable costs are not the result of the bankruptcy system itself but of the firm's poor prospects.").

${ }_{125}$ Good examples are companies which took on excessive debt to accomplish or fend off buy outs but which could not handle interest payments, including Carter Hawley Hale Stores, Campeau Corp., and Interco. Many other companies are similarly situated, although they are attempting debt-exchange offers to avoid a bankruptcy filing. Western Union and Community Newspapers, Inc. are representative of the latter group.

126 Good examples are companies which entered bankruptcy to deal with large product liability claims, such as Manville, Eagle-Pitcher Corp., and A. H. Robins.

127 See, e.g., Fortgang \& Mayer, supra note 2, at 113-14 (noting that management at times acts for the debtor at the expense of the creditors by, for example, rejecting an executory contract which increases the debtor's cash flow and therefore its value as an enterprise but results in a damage claim which is larger than the gain, thereby diluting the unsecured creditors' recovery); Roe, supra note 65 , at $266-67$ ("IT]he 
zation process by virtue of its control over the debtor and by virtue of the exclusivity period. ${ }^{128}$ Meanwhile, collective action problems hinder creditors in opposing management. The result is that management's notion of how the reorganization should proceed may be the only notion given due consideration. A veto exercised by a claim purchaser may be the only mechanism ensuring that an alternative notion is considered fully.

\section{TOWARDS A FRAMEWORK FOR APPLYING SECTION 1126(e)}

Workout negotiations take place in the shadow of chapter 11 bankruptcy negotiations, which in turn, take place in the shadow of a voting contest for approval of a plan of reorganization. ${ }^{129}$ Thus, impairment of the voting rights attached to a claim weakens the negotiating position of its holder at each prior stage and as a result reduces the value of the claim even if the process never comes to a contested vote. ${ }^{130}$

The cumulative loss to original claim holders caused by voting restrictions placed on claim purchasers may be substantial, yet may be difficult for a judge to see or measure. On the other hand, the gains which result from a vote disqualification in a single, particularly contentious case are easy for a judge to see. Confirmation of a plan moves that case a giant step closer to completion. ${ }^{131}$ Further, claims purchasers may be too readily labeled "vultures,"

current framework for reorganization gives managers, presumed to be allies of shareholders, substantial control over the reorganization process. Managers might delay in hope of an economic upturn and a resurgence of the bankrupt firm.").

${ }^{128}$ See supra notes 119-14.

129 See generally Roe, supra note 65, at 253-79 (discussing how aspects of bankruptcy law affect the strategic action of parties prior to the bankruptcy).

${ }^{130}$ See In re Lorraine Castle Apartments Bldg. Corp., 149 F.2d 55, 58 (7th Cir.), cert. denied, 326 U.S. 728 (1945) (holding that allowing a claims purchaser to participate only to the extent of the price he paid for the claim rather than the claim's par value "would result in unearned, undeserved profit for the debtor, [and] destroy or impair the sales value of securities by abolishing the profit motive, which inspires purchasers"); Note, Equity Power of Bankruptcy Courts Over Classification and Assignment of Claims, 50 YALE L.J. 892, 899 n.47 (1941) ("Speculation alone is not a danger. Too rigid restriction upon speculative activity would depress the market prices of claims and prevent financially pressed creditors from unloading prior to lengthy reorganization proceedings." (citations omitted)).

131 This observation is especially true when the case is a large, complex bankruptcy which has plagued the court's calendar for many months. Allegheny, for example, traversed 22 months in bankruptcy and 12 reorganization plans before a plan was confirmed, though Japonica had only been involved for a fraction of that time. See In re Allegheny Int'l, Inc., 118 Bankr. 282, 285-86 (Bankr. W.D. Pa. 1990). 
precluding adequate consideration of the positive aspects of the role they play. ${ }^{132}$ The result will often be a finding of bad faith, which serves as poor precedent.

The most equitable safeguard is to give the claims purchaser the benefit of a presumption of good faith for the purposes of section 1126(e). Bankruptcy courts have not been consistent in their placement of the burden of showing the motive or effect of the claim purchaser's participation. ${ }^{133}$ The presumption would force the court to begin its analysis from a point which recognizes the claim purchaser's economic contributions. As discussed, those contributions include the abilities to supply liquidity to creditors, to counter management power, to consolidate claims, and to recapitalize the debtor.

The veto right of a claim holder with enough votes is plain from a reading of the Bankruptcy Code. ${ }^{134}$ To undermine the veto right through a restrictive application of section $1126(\mathrm{e})$ may be expedient in a particular reorganization, but it disserves stakeholders in subsequent reorganizations by denying them the benefits of claim purchaser participation. The presumption of good faith would force the party seeking to disqualify the claim purchaser's vote to show that an undue delay or an improper motive has undercut the benefits which normally accrue.

In order to be meaningful, the presumption of good faith must be accompanied by more specific guidance as to what constitutes an improper motive. As discussed, the test invariably applied is that articulated in $P-R$ Holding: an ulterior motive is one which is in aid of an interest other than an. interest as a creditor. ${ }^{135}$ The variable is how permissively one's "interest as a creditor" will be interpreted by the court. The more permissive interpretation would allow a claim holder to seek a relationship with the reorganized entity if that would maximize the return on its claim. Other claim holders are clearly already allowed to seek such relationships. ${ }^{136}$ Thus,

132 See supra notes 24-35 and accompanying text.

${ }^{133}$ Compare In re Landau Boat Co., 8 Bankr. 432, 435 (Bankr. W.D. Mo. 1981) (placing the burden on the debtor to establish claim holder's improper motive before asking claim holder to testify regarding its motive) with Allegheny, 118 Bankr. at 289 (placing burden on claim purchaser to justify its motives).

134 See supra note 10 and accompanying text.

135 See supra notes 68-71 and accompanying text.

136 For example, trade claimants may agree to a lesser payment in the reorganization plan to encourage a profitable relation with the reorganized company. Employees may similarly believe their interests are best pursued in post reorganization contract negotiations. 
claim purchasers are put on the most equal footing and claim sellers receive fullest value if purchasers can properly have the furtherance of a relationship with the reorganized entity as their motive. In the case of claim purchasers, the relationship would most likely be that of stockholder. ${ }^{137}$

The most pronounced effect of a presumption of good faith would be to eliminate consideration of the timing and pricing of claim purchases in the good faith calculus. Timing and pricing offer no direct evidence as to motive, ${ }^{138}$ which is the key element in the good faith determination. ${ }^{139}$ Statutory language never stated or implied that the timing or pricing of claim purchases should be assigned importance. ${ }^{140}$ Consideration of timing and pricing tend to cloud the issue of motive ${ }^{141}$ and should, therefore, be eliminated.

The net effect of the presumption recommended here will probably be to further the adoption of the permissive approach in the bankruptcy courts. Courts which have focused on the issue of motive have most often found blocking minorities to be within their economic rights as long as the minorities were trying to maximize returns on their investment in the debtor. ${ }^{142}$ The next logical question is whether adoption of the permissive approach to good faith is a good result. The answer is affirmative if one is convinced that the benefits of claim purchaser participation in the reorganiza-

${ }^{137}$ Having the motive of becoming a controlling stockholder is more problematic. Presumably only one party can be the controlling stockholder, and thus to demand that position in return for one's vote would violate the prohibition against discriminatory treatment within a class, articulated in Young v. Higbee Co., 324 U.S. 204 (1945). See supra note $62-63$ and accompanying text.

${ }^{138}$ See, e.g., In re Lorraine Castle Apartments Bldg. Corp., 149 F.2d 55, 58 (7th Cir.), cert. denied, 326 U.S. 728 (1945) (holding that a late purchase of a security for a discounted price did not supply the "equitable reason" necessary to limit the security holder's participation in the reorganization).

${ }^{139}$ See In re P-R Holding Corp., 147 F.2d 895, 897 (2d Cir. 1945) (stating that " $[w]$ hen [a] purchase is in aid of an interest other than an interest as a creditor, such purchase may amount to 'bad faith'"); In re Pine Hill Collieries Co., 46 F. Supp. 669, 671 (E.D. Pa. 1942) (stating that the test of "good faith" lies in the motives of the holder of the claims).

140 Section 203 of the Bankruptcy Act stated that the judge could find bad faith "in light of or irrespective of the time of acquisition" of the claim. Section 203 made no mention at all of pricing. Though section 1126(e) of the Bankruptcy Code was derived from section 203 of the Bankruptcy Act, section 1126(e) makes no mention at all of either timing or pricing in the good faith inquiry. See supra notes $49-51$ and accompanying text.

141 See supra note 106 and accompanying text.

142 See supra notes 55-56. 
tion process outweigh the costs. ${ }^{143}$ Even those people who are not so convinced will still probably agree that uncertainty as to what the law says is costly to both buyers and sellers in the claims market. It is precisely the uncertainty in the law surrounding the application of section 1126(e) which is most intolerable.

The application of section 1126(e) to claim purchasers needs clarification. Voting power in bankruptcy impacts negotiating power both before and after the bankruptcy filing. The parties to a bankruptcy and the parties participating in the market for claims must understand what actions constitute bad faith in order to adjust their pricing and behavior. A presumption of good faith in favor of claim purchasers can be used to clarify the limits of good faith and to facilitate a liquid, efficient market in claims.

143 See supra notes 25-35 \& 120-26 and accompanying text (arguing that the benefits are substantial and increasing while the costs are low and declining). 